\title{
Molecular Responses of Arabidopsis MET1 Cytosine Methyltransferase Mutants to Salinity
}

\section{Yağmur Vecide Yeşildirek}

Istanbul University: Istanbul Universitesi

\section{Burcu Arikan}

Istanbul University: Istanbul Universitesi

Neslihan Turgut Kara ( $\square$ neslihantk@istanbul.edu.tr)

Istanbul University: Istanbul Universitesi https://orcid.org/0000-0001-5355-4937

\section{Research Article}

Keywords: Arabidopsis thaliana, epigenetics, telomerase, qPCR, abiotic stress.

Posted Date: March 1st, 2022

DOl: https://doi.org/10.21203/rs.3.rs-974453/v2

License: (a) (i) This work is licensed under a Creative Commons Attribution 4.0 International License. Read Full License 


\section{Abstract}

In this study, we investigated the morphological and molecular responses of Arabidopsis met 1-7 and met1-3 null mutants under salinity stress. In this context, global DNA methylation changes of mutants exposed to salt stress were compared and expressions of DRM2, Pol IV and Pol Vgenes known to be involved in DNA methylation in plants were analyzed. We found that met1-7 and met1-3 mutants have a higher rate of hypomethylation than Col-0 under all conditions. According to the results of gene expression analysis, the increase in expression of DRM2, Pol IV and Pol V genes involved in CNN methylation in mutants than Col-0 plant suggests that hypomethylation is directly related to CG regions, but in met1 mutants, the lack of CG methylation is tried to be compensated by RdDM. In addition, we analyzed the expression of the TERT gene as a stress response indicator in order to examine the effect of salt stress on the telomerase enzyme in met 1-7 and met1-3 mutants. Contrary to expected, we found that there was an increase in the expression of TERT gene in the salt stress applied plants. Within the scope of all the data, it is thought that in met1 mutants RdDM pathway is activated in order to deal with the lack of DNA methylation in CG islands. As a conclusion, it is believed that the morphological and molecular data obtained on the effects of $\mathrm{NaCl}$ application to met1 mutants will help us to understand the epigenetic basis of stress mechanisms.

\section{Introduction}

Plants have a major impact on ecosystem balance. They have important roles such as being food sources for animals and humans. However, it has become difficult to provide the required amount of food due to the increasing population and the decrease in agricultural areas as a result of salinity and drought stress. The first step to find solutions to these problems is to understand the relevant pathways very well in model organisms such as Arabidopsis thaliana.

After salt exposure molecular mechanisms are activated in plants in order to tolerate stress conditions. Epigenetic modifications, one of these molecular mechanisms, affect the stability of the genome by changing the covalent bonds between DNA and protein without changing the DNA structure. Studies have shown that epigenetic modifications can mediate stress tolerance memory during repeated exposure to certain environmental stresses. Some genetic changes that can occur in plants' reproductive cells throughout their lifetimes can then be passed on to subsequent generations. For this reason, plant systems are a rich resource for the study of epigenetic inheritance (Molinier et al. 2006; Henderson and Jacobsen 2007; Kinoshita and Seki 2014).

DNA methylation, which is one of the most common epigenetic modifications in $A$. thaliana, accounts for about $30 \%$ of its genome (Haag and Pikaard 2011; Sahu et al. 2013). Cytosine methylation in plants occurs in three types: CG, CNG as symmetric and CNN as asymmetric (where N represents A, T, or C) (Kong et al. 2018). There are 3 enzymes mainly involved in the methylation of cytosine in plants. The first enzyme is methyltransferase 1 (MET1), which is responsible for methylation of CG sequences and a homologue of the mammalian DNMT1. The second enzyme responsible for methylation of CNG and a small amount of CNN sequence is chromomethylase 3 (CMT3). This plant-specific enzyme is largely deposited in TE's and induces ectopic methylation of protein-coding genes. It is also thought to depend on direct physical binding to $\mathrm{H} 3 \mathrm{~K} 9 \mathrm{me} 2$ to target chromatin and methylation. The third enzyme, domains rearranged methylase (DRM), which is a 
homologue of DNMT3 in mammals, is mainly responsible for maintaining asymmetric CNN methylation with siRNAs and plays a minor role in the maintenance of CNG methylation. Also it is required for de novo methylation of cytosines in all sequence contexts (Ashapkin et al. 2002; Henderson and Jacobsen 2007; Johnson et al. 2007; Law and Jacobsen 2010; Wendte et al. 2019; Papareddy et al. 2021). However, plants have developed a unique de novo DNA methylation pathway called RNA-directed DNA methylation (Quadrana and Colot 2016; Brocklehurst et al. 2018). Plant specific Pol IV and Pol V derived from Polymerase II (Pol II) play roles in RNA-directed DNA methylation (Chinnusamy and Zhu 2009; Zhang and Zhu 2011). Pol IV is responsible for the biosynthesis of siRNAs, while Pol V is responsible for targeting the siRNAs to loci affected by DNA methylation (Haag and Pikaard 2011).

Telomeres are known to be very sensitive to changing environmental conditions plants are exposed. Studies have shown that telomeres shorten under increasing stress conditions (Von Zglinicki 2002; Chan and Blackburn 2004; Houben et al. 2008). In other words, defects in the expression of TERT gene and as well as methylation can cause developmental anomalies (D'Amico-Willman et al. 2021). Moreover, it has been observed that after a certain period of time, when stress conditions disappear, telomeres lengthen again. Hence, the search for TERT expression has the potential to be an indicative biomarker.

Studies have been conducted using the met1-7and/or met1-3 mutants, but the molecular changes that occur as a result of salinity stress have not been studied (Jullien et al. 2006; Pontvianne et al. 2013; Rigal et al. 2016; Blevins et al. 2017). Arıkan et al. (2018) stated in their study that salt stress causes hypomethylation in plants and this hypomethylation is not only related to the MET1 gene. Besides this, DRM2-related de novo methylation is also affected. Considering these studies, molecular mechanisms must be understood well in order to make plants resistant to the stress conditions they encounter and maintain this resistance for generations. Consequently, it was decided to examine the effect of salt on met1-7 and met1-3 mutants to understand the role of the MET1 gene under salt stress.

In this study, to understand the relationship between the hypomethylation caused by $\mathrm{NaCl}$ stress and the MET1 gene, $A$. thaliana Col-0 plants and null mutants of met1-7 and met1-3 were exposed to salt stress. To this extent, methylation level of the genome and the expressions of $D R M 2, P o l / V$ and $P o / V$ genes, which are known to be involved in the RdDM mechanism were analyzed. Also the expression of the TERT gene was analyzed in order to examine the effects of salt stress on the telomeres of met1 mutants.

\section{Material And Methods}

\section{Plant material and growth conditions}

A. thaliana Col-0 (Wild type), met1-7 and met1-3 seeds were kindly provided from Dr. Ralf Stracke (Bielefeld University, Center for Biotechnology), Dr. Binglian Zheng (Fudan University, Department of Biochemistry and Molecular Biology) and Dr. Hidetoshi Saze (Plant Epigenetics Unit, Okinawa Institute of Science and Technology), respectively. met1-7 and met1-3 lines have been described previously and backgrounds of these two mutants are based on the Col-0 ecotype (Saze et al. 2003; Li et al. 2017).

The Col-0, met1-7, and met1-3 seeds were surface sterilized and placed on Murashige and Skoog basal medium (MS) (Murashige and Skoog 1962) which was supplemented with sucrose (3\%, w/v) and pH was adjusted to 
5.8. Agar $(0.9 \%, \mathrm{w} / \mathrm{v})$ was added for solidifying and the medium was sterilized by autoclaving at $121^{\circ} \mathrm{C}$ under 1 atm pressure for 15 minutes. Col-0, met1-7 and met1-3 seeds were germinated under fluorescent light in a plant growth chamber [16 hours light / 8 hours dark conditions, 1400 lux (Sanyo, MLR-352H)] at $25^{\circ} \mathrm{C}$ like as Arıkan et al. (2018).

\section{Bioinformatic analysis on MET1 enzyme}

Self-fertilization and seeding studies performed in our laboratory gave positive results in met1-7, but were inconclusive in met1-3 similar with Saze et al. (2003). The fact that the two met1 mutants morphologically different significantly from each other and after observing only met1-7 mutant seed yields, the regions where the T-DNA insert entered were examined in more detail to investigate the answer that may have caused this difference.

The bacterial Ti-plasmid (T-DNA) inserts disrupt the conserved regions by entering the beginning of the 2 nd exon in the met1-7 mutants and at the beginning of the 7th exon in the met1-3 mutants (TAIR 2021a, 2021b). The locations of the T-DNA inserts in the mutants are shown in Fig. 1.

The amino acid sequences of the $A$. thaliana MET1 enzyme (NP_199727.1) were obtained from the NCBI site (https://www.ncbi.nlm.nih.gov/protein/) and the catalytic sites of the enzyme were obtained using the 'Conserved Domain Database, CDD" program on NCBI (https://www.ncbi.nlm.nih.gov/cdd/). The exon sequences disrupt by the T-DNA regions were converted into amino acid sequences with the 'Translated BLAST: blastx' program (https://blast.ncbi.nlm.nih.gov ) and the projections of the MET1 enzyme on the amino acid sequences were determined by the BLASTp program (https://blast.ncbi.nlm.nih.gov ). Then, the regions were colored using the ChimeraX (version 1.1) program (https://www.cgl.ucsf.edu/chimerax/) for reevaluating the importance of T-DNA insertion sites on enzyme activity (Pettersen et al. 2021).

\section{Stress treatment and morphological analysis}

Seven days old $A$. thaliana Col-0, met1-7 and met1-3 plants germinated on MS medium were transferred to MS medium containing 0,100 and $150 \mathrm{mM} \mathrm{NaCl}$ for stress application. Col-0, met1-7 and met1-3 plants were incubated 7 days under fluorescent light in a plant growth chamber $[16$ hours light / 8 hours dark conditions, 1400 lux (Sanyo, MLR-352H)] at $25^{\circ} \mathrm{C}$.

The number of leaves, leaf surface area and root length of Arabidopsis met1-7 and met1-3 plants were determined and later compared morphologically with the control group. Leaf surface areas of $A$. thaliana plants were calculated according to the equation used by Carus and Çatal (2005). After the morphological analysis, the collected plant samples were kept at $-80^{\circ} \mathrm{C}$ until the usage in molecular analysis.

\section{DNA isolation and global DNA methylation (5-mC) level analysis}


100 mg plant sample was harvested from each group treated with $\mathrm{NaCl}$ stress and DNA isolation was carried out with a GeneJET Plant Genomic DNA Purification Kit (Thermo Scientific, K0792) according to the manufacturer's protocol. Global methylation changes (\%) in genomic DNA were detected by MethylFlash Global DNA Methylation (5-mC) ELISA Easy Kit (EpiGentek, p-1030) according to the manufacturer's protocol. The 5$\mathrm{mC}$ in the DNA of all biological samples were reported as the amount of methylated cytosine relative to the genomic content (percentage) of cytosine (Tellez-Plaza et al. 2014).

\section{RNA isolation and qPCR analysis}

For qPCR analysis, total RNA was isolated with Hibrizol (Hibrigen, Turkey) from A. thaliana Col-0, met1-7, and met1-3 plants exposed to $\mathrm{NaCl}$ stress. Then, the RNAs were checked for their integrity, purity and quantity. Their purities and quantities were checked by NanoDrop 2000 (Thermo Scientific) and their integrities were analyzed by agarose gel electrophoresis (\%1 TAE). cDNA was synthesized using the High-Capacity cDNA Reverse Transcription Kit (Thermo Scientific, 4368814) according to the manufacturer's recommended protocol.

qPCR amplification was performed with a Roche LightCycler Nano instrument by using 2X SYBR Green Master mix (Hibrigen, 0220-UB-775). The following PCR protocol was applied: $50^{\circ} \mathrm{C} / 30 \mathrm{~s}$, followed by 40 cycles of $94^{\circ} \mathrm{C} / 30 \mathrm{~s}, 59^{\circ} \mathrm{C} / 61^{\circ} \mathrm{C} / 65^{\circ} \mathrm{C}$ for $30 \mathrm{~s}\left(59^{\circ} \mathrm{C}\right.$ for TERT, $61^{\circ} \mathrm{C}$ for Actin, Pol IV, Pol $V$ and $65^{\circ} \mathrm{C}$ for $D R M 2$ respectively) and $72^{\circ} \mathrm{C}$ for $30 \mathrm{~s}$. qPCR reactions were carried out with 2 technical replicates for each 3 biological replicates. The fold changes were calculated using $2^{-\Delta \Delta C t}$ values, and relative expressions were shown as log2 fold changes (Livak and Schmittgen 2001). The primer sequences are given in Table 1. TERT gene (AT5G16850) primer pair was designed using the Primer3 program (http://primer3.ut.ee/).

Table1 The primer sequences used in gene expression analysis

\begin{tabular}{|lll|}
\hline Gene & Primers & References \\
\hline DRM2 & F: 5'-AACAAAGCTGCCCCACTCG-3' & Naydenov et al., 2015 \\
& R: 5'-ATACGCCACAGTATCAACCTG-3' & \\
\hline Pol IV & F: 5'-GAAACGCATTCTCCACAGTTAC-3' & Naydenov et al., 2015 \\
& R: 5'-GCGACCCGGATTCCTTTGAC-3' & \\
\hline Pol V & F: 5'-CATCCGTCTGCGTACCCTG-3' & Naydenov et al., 2015 \\
& R: 5'-TCAACCGTGATGAAGTCAACG-3' & \\
\hline TERT & F: 5'-AATCTCCCGCCTCTTTCACA-3' & \\
& R: 5'-GTTTACGCGGCATTACACCT-3' & \\
\hline Actin 8 & F: 5'-GCCAGTGGTCGTACAACCG-3' & Sáenz-Mata et al., 2012 \\
& R: 5'- TCATGAGGTAATCAGTAAGGTCAC -3' & \\
\hline
\end{tabular}

\section{Statistical analysis}


Morphological experiments with $A$. thaliana met1-7 and met1-3 plants, evaluation of the results obtained with the "MethylFlash ${ }^{\text {TM }}$ Methylated DNA Quantification" kit, and gene expression analysis were statistically performed using the GraphPad Prism ${ }^{\circledR} 7.0$ software using two-way ANOVA with post-hoc Tukey's test. Results with $p<0.05$ were considered significant. Morphological experiments were performed on at least 30 plants for each replicate (in total 3 biological replicates), and methylation level analysis as well as gene expression analysis were performed with 3 biological and 2 technical replicates.

\section{Results}

\section{Morphological effects of stress application}

The morphologies of the met1-7, met1-3 null mutants and the control plants after 7 days exposure to $\mathrm{NaCl}$ stress are given in Fig. 2. As a result of the morphological analysis, leaf number for different $\mathrm{NaCl}$ concentrations in the control group Col-0 and met1-7, met1-3 null mutants did not change significantly between the groups. But the number of leaves was significantly reduced within all plant groups except in the met1-3 mutants between the 100 and $150 \mathrm{mM} \mathrm{NaCl}$ concentrations.

It was observed that the leaf surface areas decreased significantly between control and $150 \mathrm{mM} \mathrm{NaCl}$ concentrations in the Col-0 plants. Also, it was observed that the leaf surface areas of met1-3 mutants were affected more than the met1-7 mutants after $150 \mathrm{mM} \mathrm{NaCl}$ application.

And finally, it was observed that the root length decreased significantly except between the control group and the $100 \mathrm{mM} \mathrm{NaCl}$ application in both mutants. Compared to Col-0, met1-3 was more sensitive to salt stress than met1-7 plant and root length was significantly shortened in all groups. The root length was significantly shortened between the control group of met7-7 and the Col-0, also between each $\mathrm{NaCl}$ concentrations applied to met1-3 and Col-0. Lastly, the root length was decreased between both mutants for each concentration. The graphs of the morphological analysis are given in Fig. 3 , and in addition to the graphical data, average values and standard errors are also given in Table 2.

Table2 Determination of the morphological effects of different $\mathrm{NaCl}$ concentrations in Col-0, met1-7 and met1-3 plants. Each value represents the average of repetitions and the standard error $( \pm \mathrm{SH})$ 


\begin{tabular}{|c|c|c|c|c|}
\hline \multirow[t]{4}{*}{ Col-0 } & $\mathrm{NaCl}(\mathrm{mM})$ & Leaf Number & Leaf Surface Area $\left(\mathrm{cm}^{2}\right)$ & Root Length $(\mathrm{cm})$ \\
\hline & 0 & $9.047 \pm 0.216$ & $0.405 \pm 0.032$ & $4.097 \pm 0.169$ \\
\hline & 100 & $7.195 \pm 0.235$ & $0.346 \pm 0.029$ & $2.984 \pm 0.141$ \\
\hline & 150 & $5.787 \pm 0.215$ & $0.269 \pm 0.020$ & $1.560 \pm 0.090$ \\
\hline \multirow[t]{4}{*}{ met1-7 } & $\mathrm{NaCl}(\mathrm{mM})$ & Leaf Number & Leaf Surface Area $\left(\mathrm{cm}^{2}\right)$ & Root Length (cm) \\
\hline & 0 & $8.455 \pm 0.261$ & $0.409 \pm 0.033$ & $2.922 \pm 0.152$ \\
\hline & 100 & $6.936 \pm 0.238$ & $0.328 \pm 0.026$ & $2.800 \pm 0.124$ \\
\hline & 150 & $5.605 \pm 0.265$ & $0.292 \pm 0.034$ & $2.023 \pm 0.120$ \\
\hline \multirow[t]{4}{*}{ met1-3 } & $\mathrm{NaCl}(\mathrm{mM})$ & Leaf Number & Leaf Surface Area $\left(\mathrm{cm}^{2}\right)$ & Root Length (cm) \\
\hline & 0 & $8.313 \pm 0.362$ & $0.266 \pm 0.023$ & $2.124 \pm 0.144$ \\
\hline & 100 & $6.682 \pm 0.297$ & $0.234 \pm 0.031$ & $1.600 \pm 0.197$ \\
\hline & 150 & $5.500 \pm 0.336$ & $0.137 \pm 0.020$ & $0.640 \pm 0.092$ \\
\hline
\end{tabular}

\section{T-DNA insertion region in 3D structure of MET1 enzyme}

The analysis with ChimeraX Program (version1.1) showed that the region disrupted by the T-DNA insert in the met1-7 mutant does not coincide with any of the 4 active regions of the MET1 protein (NP_199727.1) consisting of 1534 amino acids where as the T-DNA insert of the met1-3 mutant disrupts the active site where S-adenosylmethionine (SAMe) binds to the methyltransferase1 protein (Fig. 4).

\section{Global DNA methylation}

As a result of the methylation analysis, mutants were found to be less methylated than $\mathrm{Col}-0$ in each $\mathrm{NaCl}$ concentration. In control conditions, met1-3 mutants had less methylation compared to met1-7, but there was no significant change in met1-3 between applied $\mathrm{NaCl}$ concentrations, while hypomethylation occurred between control and $100 \mathrm{mM}$ in met1-7. In addition, it was observed that between 100 and $150 \mathrm{mM} \mathrm{NaCl}$ treatments methylation increment has occurred. These findings could indicate that the treatment with $150 \mathrm{mM} \mathrm{NaCl}$ could have activated additional mechanisms in the met1-7 mutant other than met1-3. However, when considering the entirely, mutants were found to be less methylated than $\mathrm{Col}-0$ at each $\mathrm{NaCl}$ concentration. The results of methylation analysis are given in Fig. 5, and the percentages of methylation levels and standard errors are given in Table 3.

Table3 Determination of the global DNA methylation percentages and standard errors of Col-0, met1-7 and met1-3 plants after different concentrations of $\mathrm{NaCl}$ treatment 


\begin{tabular}{|llll|}
\hline $\mathrm{NaCl}(\mathrm{mM})$ & Col-0 & met1-7 & met1-3 \\
\hline $\mathbf{0}$ & $4.726 \pm 0.296$ & $4.176 \pm 0.146$ & $2.452 \pm 0.032$ \\
\hline $\mathbf{1 0 0}$ & $3.752 \pm 0.068$ & $1.979 \pm 0.116$ & $2.700 \pm 0.027$ \\
\hline $\mathbf{1 5 0}$ & $4.888 \pm 0.541$ & $3.936 \pm 0.114$ & $2.994 \pm 0.281$ \\
\hline
\end{tabular}

\section{Expression of DRM2, Pol IV, Pol V and TERT genes}

As a result of the analysis, expression of the DRM2 gene changed by 0.4 fold in $A$. thaliana Col-0 plant after 100 $\mathrm{mM} \mathrm{NaCl}$ application compared to control, and increased by 1.4 and 1.2 fold in met1-7 and met1-3, respectively. And there was no change in Col-0 after $150 \mathrm{mM} \mathrm{NaCl}$ application, while it was increased by 1.65 and 1.45 fold in met1-7 and met1-3, respectively. In the expression change of $P o l ~ I V$ gene, it was determined that $100 \mathrm{mM}$ $\mathrm{NaCl}$ application caused an increase in met1-7 and met1-3 groups 1.37 and 2 fold respectively, while $150 \mathrm{mM}$ $\mathrm{NaCl}$ application caused an increase of 1.7, 2.73 and 1.95 fold at Col-0, met1-7 and met1-3 plants, respectively. The expression of $P o l V$ gene after $100 \mathrm{mM} \mathrm{NaCl}$ application caused an increase of 1.3, 2.1 and 1.55 fold in Col-0, met1-7 and met1-3 groups respectively. After $150 \mathrm{mM} \mathrm{NaCl}$ application, the expression of Pol $V$ gene in Col-0 plant was changed by 0.7 fold, while in mutants it was increased by 2.85 and 1.8 fold, respectively. Lastly, the expression of TERT gene in Col- 0 after $100 \mathrm{mM} \mathrm{NaCl}$ application changed by 0.6 fold, while in met1-7 and met1-3 mutants it was increased by 1.7 and 1.5 fold, respectively. After $150 \mathrm{mM} \mathrm{NaCl}$ application, the expression of TERT gene in Col-0 plant was changed by 0.7 fold, while in met1-7 and met1-3 mutants it was increased by 1.6 and 1.2 fold, respectively. As a result of the two-way ANOVA with post-hoc Tukey test, there was a statistically significant increment of TERT gene expression between Col-0 and met 1 mutants at $100 \mathrm{mM}$ $\mathrm{NaCl}$ application. Statistical significance was not determined in the expression analysis among other genes. The graphical representation of the gene expression analysis is given in Fig. 6 and relative fold changes are given in Table 4.

Table 4

Relative expression fold change values of $D R M 2, P o l I V, P o l V$ and TERT genes.

\begin{tabular}{|c|c|c|c|c|c|c|c|c|c|c|c|c|}
\hline \multirow[b]{2}{*}{$\begin{array}{l}\mathrm{NaCl} \\
(\mathrm{mM})\end{array}$} & \multicolumn{3}{|c|}{ DRM2 } & \multicolumn{3}{|c|}{ Pol IV } & \multicolumn{3}{|c|}{ Pol V } & \multicolumn{3}{|c|}{ TERT } \\
\hline & $\begin{array}{l}\text { Col- } \\
0\end{array}$ & ${ }_{7}^{\text {met1- }}$ & $\operatorname{met}_{3}$ & $\begin{array}{l}\text { Col- } \\
0\end{array}$ & $\begin{array}{l}\text { met1- } \\
7\end{array}$ & ${ }_{3}^{\operatorname{met} 1-}$ & $\begin{array}{l}\text { Col- } \\
0\end{array}$ & $\begin{array}{l}\text { met1- } \\
7\end{array}$ & $\begin{array}{l}\text { met1- } \\
3\end{array}$ & $\begin{array}{l}\text { Col- } \\
0\end{array}$ & $\begin{array}{l}\text { met1- } \\
7\end{array}$ & ${ }_{3}^{\text {met1- }}$ \\
\hline 0 & 1 & 1 & 1 & 1 & 1 & 1 & 1 & 1 & 1 & 1 & 1 & 1 \\
\hline 100 & 0.4 & 1.4 & 1.2 & 1 & 1.37 & 2 & 1.3 & 2.1 & 1.55 & 0.6 & 1.7 & 1.5 \\
\hline 150 & 0.95 & 1.65 & 1.45 & 1.7 & 2.73 & 1.95 & 0.7 & 2.85 & 1.8 & 0.7 & 1.6 & 1.2 \\
\hline
\end{tabular}

\section{Discussion}

Salt stress that plants encounter in nature is usually caused by $\mathrm{NaCl}$ (Ngara and $\mathrm{Ndimba} 2014)$. High $\mathrm{NaCl}$ concentrations in soils cause ionic stress by disrupting the ionic balance of $\mathrm{Na}^{+}, \mathrm{Cl}^{-}, \mathrm{K}^{+}$and $\mathrm{Ca}^{2+}$ together with 
osmotic stress. Excessive amounts of $\mathrm{Na}^{+}$ions entering the stem cells are carried to other leaves, tissues and organs and tried to be tolerated. This situation causes morphological changes in plants (Yang and Guo 2018; Liu et al. 2019). Considering all this information, in this study leaf number, leaf surface area and root length of epigenetic mutant plants treated with 100 and $150 \mathrm{mM} \mathrm{NaCl}$ during 7 days were examined. Similar to our morphological results, Arıkan et al. (2018) reported that the application of 100 and $150 \mathrm{mM} \mathrm{NaCl}$ to Arabidopsis Col-0 plants restricted root and shoot growth. Also, Baek et al. (2011) stated that the met1-3 mutant was hypersensitive to $\mathrm{NaCl}$ and they observed a salt-sensitive phenotype in root growth, and this situation could be attributed to the loss of methylation in the putative small RNA target region in the AtHKT1 promoter. In a previous study, it was stated that after 75 and $150 \mathrm{mM} \mathrm{NaCl}$ application, the met 1-3 mutants were sensitive to salt stress, although not at the same degree as the $d d m 1$ mutants (Yao et al. 2012). Moreover, Huang et al. (2013) stated that the epigenetic mutants (ros 1 and rdm16ros1) of Arabidopsis plants were adversely affected morphologically with 75, 100 and $125 \mathrm{mM} \mathrm{NaCl}$ application at seedling stage. Similar to all this research, we have found that the met1-3 mutant is more sensitive to salt stress than the met1-7 mutant, morphologically. In many studies, this morphological sensitivity observed in epigenetic mutants compared to Col-0 plants supports the importance of epigenetic mechanisms in plant development.

In addition to the analysis of mutants' responses to salt stress, seed productivity was also analyzed. In order to obtain homozygous mutant seeds, seeds were tried to be obtained by self-fertilization method. Seeds could be obtained from the met1-7 mutant, while they could not be obtained from the met1-3 mutant. This has led us to think that in the met1-3 plant, unlike met1-7, the insertion of the T-DNA insert at the beginning of the 7th exon may cause some defects in the alternative arrangements of RNA transcripts, and this may disrupt the functioning of some pathways involved in gametophyte formation. In previous studies, it was stated that the seeds of the met1-3 mutant were smaller than normal and the plants in the first generation were sterile (FitzGerald et al. 2008). However, the cause of infertility is not specified. We attribute the reason for this problem, which we encountered with this study, that the T-DNA insert entering the met1-3 mutant exactly coincides with the active region of the MET1 protein. Bioinformatic analysis showed that the T-DNA insertion in met1-3 mutant most probably disrupts the active site where S-adenosylmethionine (SAMe) binds to the methyltransferase1 protein. It is thought that the disrupted region in the met1-7 mutant may not cause any impairment in its function, although it disrupts the 3D structure of the protein. It is thought that MET1 protein, which is known to play an active role in embryogenesis, causes infertility due to its inability to function properly.

Stress responses in plants cause changes in methylation in the coding region of genes involved and regulate gene expression (Sudan et al. 2018). For this reason, detecting epigenetic changes in the plant genome shows great importance in the understanding of stress responses of plants. DNA methylation is mostly observed on cytosine bases. The main enzymes responsible for cytosine methylation in plants are MET1, CMT3 and DRM2. The MET1 enzyme, which has a great role in these regulations, is responsible for $80-90 \%$ of the cytosine-level methylation in plants (Zangi et al. 2020). In this study, we used the null mutants met1-7and met1-3, in which the functional MET1 enzyme of $A$. thaliana plant is not synthesized. The methylation changes of these met1 mutants were investigated and the 5-mC content at the genome level was determined. Likewise, Arıkan et al. (2018), the application of 100 and $150 \mathrm{mM} \mathrm{NaCl}$ during 7 days to $A$. thaliana Col-0 plant caused hypomethylation at the genome level. Boyko et al. (2010) reported in their study that unlike Arıkan et al. (2018), they encountered hypermethylation in the progeny of Arabidopsis plants exposed to salt stress. Moreover, Zhong et al. (2009) indicated that salt stress caused hypermethylation in some regions of the genome even 
though hypomethylation was found overall in the genome as a result of application of 100 and $150 \mathrm{mM} \mathrm{NaCl}$ during 5 days to bread wheat ("Triticum aestivum L.").

As with many cellular signaling pathways, molecular responses to salt stress are expected to be influenced by negative regulation as well as positive regulation of the gene expression (Zhu 2000). In parallel with our data, Gao et al. (2020) stated that gene expression of DMR2 decreased in Ginkgo biloba at $150 \mathrm{mM} \mathrm{NaCl}$ stress, but increased in chickpea roots. These results suggest that the inactivation of the MET1 gene has an effect on hypomethylation, and in this case DRM2-related de novo methylation plays a more effective role as a compensator in met1-7 and met1-3 mutants. Also, expressions of Pol IV and Pol $V$ genes were examined in order to evaluate the $\mathrm{NaCl}$ stress application in terms of RdDM in the absence of functional MET1 enzyme. Similar to our findings, Naydenov et al. (2015) observed that Pol IV and Pol V expression also increased under heat stress and stated that the expression of these genes could change not only through RdDM but also by acting in other regulatory processes.

DNA methylation has an important role in regulating promoter activity. Many studies have shown that promoter hypomethylation occurs mostly in the CG regions and is also dependent on the methyltransferases MET1 and DRM2. Accordingly, it was concluded that the TERT gene could be controlled by the MET1 system. Defects in DNA methylation are known to lead to developmental abnormalities. Zangi et al. (2020) suggested that mutations occurring in methylation systems may affect TERT gene expression, leading to developmental anomalies. In their study, they have shown that expression levels of the TERT gene increased nearly 14 fold in homozygous met 1 mutant plants compared to wild type. At the same time, TERT gene expression increased nearly 2 fold in heterozygous met 1 mutants compared to wild type. They have reached the conclusion that the TERT gene is regulated by methyltransferases and may be involved in developmental abnormalities caused by mutation in the MET1 methyltransferase system. Zangi et al. (2020) also suggested that the mutation involved in the MET1 methyltransferase systems decreased the methylation of CG islands in the promoter of the TERT gene and consequently increased the expression of the TERT gene. It is known that overexpression of telomerase leads to telomere elongation. Therefore, it is thought that overexpression of telomerase in plants with the met1 mutation may be associated with limited growth and developmental abnormalities in Arabidopsis. It is possible that the effects and deficiencies of the met 1 mutation can be compensated by other methylation systems, thereby improving the phenotype (Zangi et al. 2020). Despite this, Ogrocká et al. (2012) reported that DNA methylation in the putative TERT promoter region is not a dominant factor in the regulation of TERT transcription. They analysed the telomerase activity in met1-3 mutant seedlings, they have found no significant change in TERT transcription. Whereas, repeated analysis with met1-3 mutants revealed significantly lower telomerase activity in young leaves, the amount of TERT transcript in young leaves of Col-0 samples and 7 day seedlings of met1-3 mutants was similar. Our result is different from Zangi et al. (2020) but similar to Ogrocká et al. (2012). The expression of TERT gene is similar in Col-0 and met1 mutants not treated with $\mathrm{NaCl}$. However, there is an increase in TERT expression compared to Col-0 in $\mathrm{NaCl}$ treated mutants. According to these findings, it was concluded that to cope up with $\mathrm{NaCl}$ stress, TERT expression was upregulated due to the increasing RdDM in the mutants.

In conclusion, hypomethylation occurred at the genome level in mutants and they were left behind morphologically compared to Col-0 plants. It is consistent with the previous reports showing that the MET1 gene negatively affects the morphological characteristics of plants under $\mathrm{NaCl}$ stress. The reason for the 
increased expression of $D R M 2, \mathrm{PO} I \mathrm{~V}, \mathrm{PO} / \mathrm{V}$, and TERT genes after $\mathrm{NaCl}$ application to met1 mutants is thought to support the RdDM pathway to cope with DNA methylation deficiency in CG islands.

In order to make plants resistant to stress, molecular stress mechanisms must be understood. It is thought that the data obtained from this study will contribute to the basic knowledge to understand the effects of salt stress on epigenetic mechanisms.

\section{Declarations}

\section{Author contributions}

YVY and NTK designed the experiments. YVY and BA performed the experiments. All authors analyzed data, wrote and approved the manuscript. All authors contributed to the final version of the manuscript.

\section{Funding}

This study was supported by the Research Fund of the Istanbul University (Project ID: 36576).

\section{Financial interests}

The authors declare they have no financial interests.

\section{Declarations}

Conflict of interest The authors declare that they have no confict of interest.

Consent to participate All authors agreed with participate in this study.

Consent for publication All authors agreed with the publication of this study. The submitted work contains original research that has not been published elsewhere.

Ethical approval This study does not contain any studies with human participants or animals performed by any of the authors.

\section{References}

1. Arıkan B, Özden S, Turgut-Kara N (2018) DNA methylation related gene expression and morphophysiological response to abiotic stresses in Arabidopsis thaliana. Environ Exp Bot 149:17-26. https://doi.org/10.1016/j.envexpbot.2018.01.011

2. Ashapkin VV, Kutueva LI, Vanyushin BF (2002) The gene for domains rearranged methyltransferase (DRM2) in Arabidopsis thaliana plants is methylated at both cytosine and adenine residues. FEBS Lett 532(3):367-372. https://doi.org/10.1016/S0014-5793(02)03711-0

3. Baek D, Jiang J, Chung JS, Wang B, Chen J, Xin Z, Shi H (2011) Regulated AtHKT1 gene expression by a distal enhancer element and DNA methylation in the promoter plays an important role in salt tolerance. Plant Cell Physiol 52(1):149-161. https://doi.org/10.1093/pcp/pcq182 
4. Blevins T, Wang J, Pflieger D, Pontvianne F, Pikaard CS (2017) Hybrid incompatibility caused by an epiallele. Proceedings of the National Academy of Sciences, 114(14), 3702-3707.

https://doi.org/10.1073/pnas.1700368114

5. Boyko A, Blevins T, Yao Y, Golubov A, Bilichak A et al (2010) Transgenerational adaptation of Arabidopsis to stress requires DNA methylation and the function of Dicer-like proteins. PLoS ONE 5(3):e9514. https://doi.org/10.1371/journal.pone.0009514

6. Brocklehurst S, Watson M, Carr IM, Out S, Heidmann I, Meyer P (2018) Induction of epigenetic variation in Arabidopsis by over-expression of DNA METHYLTRANSFERASE1 (MET1). PLoS ONE 13(2):e0192170. https://doi.org/10.1371/journal.pone.0192170

7. Carus S, Çakal Y (2005) Yaprak Yüzeyinin Karaçam (Pinus Nigra Arnold) ve Toros Sediri (Cedrus Libani A. Rich.) Fidanlarında Dip Çap ve Boy Artımı Üzerindeki Etkileri. Süleyman Demirel Üniversitesi Orman Fakültesi Dergisi 2(1302-7085):52-61

8. Chan SR, Blackburn EH (2004) Telomeres and telomerase. Philosophical Transactions of the Royal Society of London. Series B: Biological Sciences 359(1441):109-122. https://doi.org/10.1098/rstb.2003.1370

9. Chinnusamy V, Zhu JK (2009) RNA-directed DNA methylation and demethylation in plants. Science in China Series C: Life Sciences 52(4):331-343. https://doi.org/10.1007/s11427-009-0052-1

10. D'Amico-Willman KM, Anderson ES, Gradziel TM, Fresnedo-Ramírez J (2021) Relative Telomere Length and Telomerase Reverse Transcriptase (TERT) Expressions Are Associated with Age in Almond (Prunus dulcis [Mill.] DA Webb). Plants 10(2):189. https://doi.org/10.3390/plants10020189

11. FitzGerald J, Luo M, Chaudhury A, Berger F (2008) DNA methylation causes predominant maternal controls of plant embryo growth. PLoS ONE 3(5):e2298. https://doi.org/10.1371/journal.pone.0002298

12. Gao C, Deng M, Yang X, Yu W, Cai J, Shi Y et al (2020) Genome-Wide Identification and Coexpression Network Analysis of DNA Methylation Pathway Genes and their Differentiated Functions in Ginkgo biloba. L Forests 11(10):1076. https://doi.org/10.3390/f11101076

13. Haag JR, Pikaard CS (2011) Multisubunit RNA polymerases IV and V: purveyors of non-coding RNA for plant gene silencing. Nat Rev Mol Cell Biol 12(8):483-492. https://doi.org/10.1038/nrm3152

14. Henderson IR, Jacobsen SE (2007) Epigenetic inheritance in plants. Nature 447(7143):418-424. https://doi.org/10.1038/nature05917

15. Houben JM, Moonen HJ, van Schooten FJ, Hageman GJ (2008) Telomere length assessment: biomarker of chronic oxidative stress? Free Radic Biol Med 44(3):235-246.

https://doi.org/10.1016/j.freeradbiomed.2007.10.001

16. Huang CF, Miki D, Tang K, Zhou HR, Zheng Z et al (2013) A Pre-mRNA-splicing factor is required for RNAdirected DNA methylation in Arabidopsis. PLOS Genet 9(9):e1003779.

https://doi.org/10.1371/journal.pgen.1003779

17. Johnson LM, Bostick M, Zhang X, Kraft E, Henderson I, Callis J, Jacobsen SE (2007) The SRA methylcytosine-binding domain links DNA and histone methylation. Curr Biol 17(4):379-384. https://doi.org/10.1016/j.cub.2007.01.009

18. Johnson LM, Law JA, Khattar A, Henderson IR, Jacobsen SE (2008) SRA-domain proteins required for DRM2-mediated de novo DNA methylation. PLoS Genet 4(11):e1000280.

https://doi.org/10.1371/journal.pgen.1000280

Page $12 / 20$ 
19. Jullien PE, Katz A, Oliva M, Ohad N, Berger F (2006) Polycomb group complexes self-regulate imprinting of the Polycomb group gene MEDEA in Arabidopsis. Curr Biol 16(5):486-492.

https://doi.org/10.1016/j.cub.2006.01.020

20. Kinoshita T, Seki M (2014) Epigenetic memory for stress response and adaptation in plants. Plant Cell Physiol 55(11):1859-1863. https://doi.org/10.1093/pcp/pcu125

21. Kong W, Li B, Wang Q, Wang B, Duan X, Ding L et al (2018) Analysis of the DNA methylation patterns and transcriptional regulation of the NB-LRR-encoding gene family in Arabidopsis thaliana. Plant Mol Biol 96(6):563-575. https://doi.org/10.1007/s11103-018-0715-z

22. Law JA, Jacobsen SE (2010) Establishing, maintaining and modifying DNA methylation patterns in plants and animals. Nat Rev Genet 11(3):204-220. https://doi.org/10.1038/nrg2719

23. Liu B, Soundararajan P, Manivannan A (2019) Mechanisms of Silicon-Mediated Amelioration of Salt Stress in Plants. Plants 8(9):307. https://doi.org/10.3390/plants8090307

24. Livak KJ, Schmittgen TD (2001) Analysis of relative gene expression data using real time quantitative PCR and the 2- $\Delta \Delta$ CT method. Methods 25:402-408. https://doi.org/10.1006/meth.2001.1262

25. Molinier J, Ries G, Zipfel C, Hohn B (2006) Transgeneration memory of stress in plants. Nature 442(7106):1046-1049. https://doi.org/10.1038/nature05022

26. Murashige T, Skoog F (1962) A revised medium for rapid growth and bioassays with tobacco tissue cultures. Physilogia Plantarum 15(3):473-497. https://doi.org/10.1111/j.1399-3054.1962.tb08052.x

27. Naydenov M, Baev V, Apostolova E, Gospodinova N, Sablok G, Gozmanova M, Yahubyan G (2015) Hightemperature effect on genes engaged in DNA methylation and affected by DNA methylation in Arabidopsis. Plant Physiol Biochem 87:102-108. https://doi.org/10.1016/j.plaphy.2014.12.022

28. Ngara R, Ndimba BK (2014) Understanding the complex nature of salinity and drought-stress response in cereals using proteomics Technologies. Proteomics 14(4-5):611-621.

https://doi.org/10.1002/pmic.201300351

29. Ogrocká A, Sýkorová E, Fajkus J, Fojtová M (2012) Developmental silencing of the AtTERT gene is associated with increased H3K27me3 loading and maintenance of its euchromatic environment. J Exp Bot 63(11):4233-4241. https://doi.org/10.1093/jxb/ers107

30. Papareddy RK, Páldi K, Smolka AD, Hüther P, Becker C, Nodine MD (2021) Repression of CHROMOMETHYLASE 3 Prevents Epigenetic Collateral Damage in Arabidopsis. https:// doi.org/10.1101/2021.04.14.439682. bioRxiv

31. Pettersen EF, Goddard TD, Huang CC, Meng EC, Couch GS, Croll TI, Morris JH, Ferrin TE (2021) UCSF ChimeraX: Structure visualization for researchers, educators, and developers. Protein Sci 30(1):70-82. https://doi.org/10.1002/pro.3943

32. Pontvianne F, Blevins T, Chandrasekhara C, Mozgová I, Hassel C, Pontes OM et al (2013) Subnuclear partitioning of rRNA genes between the nucleolus and nucleoplasm reflects alternative epiallelic states. Genes Dev 27(14):1545-1550. https://doi.org//10.1101/gad.221648.113

33. Rigal M, Becker C, Pélissier T, Pogorelcnik R, Devos J, Ikeda Y (2016) Et al. Epigenome confrontation triggers immediate reprogramming of DNA methylation and transposon silencing in Arabidopsis thaliana F1 epihybrids. Proceedings of the National Academy of Sciences, 113(14), E2083-E2092 https://doi.org/10.1073/pnas.1600672113 
34. Sahu PP, Pandey G, Sharma N, Puranik S, Muthamilarasan M, Prasad M (2013) Epigenetic mechanisms of plant stress responses and adaptation. Plant Cell Rep 32(8):1151-1159. https://doi.org/10.1007/s00299013-1462-x

35. Sáenz-Mata J, Jiménez-Bremont JF (2012) HR4 gene is induced in the Arabidopsis-Trichoderma atroviride beneficial interaction. Int J Mol Sci 13(7):9110-9128. https://doi.org/10.3390/ijms13079110

36. Sudan J, Raina M, Singh R (2018) Plant epigenetic mechanisms: role in abiotic stress and their generational heritability. 3 Biotech 8(3):172. https://doi.org/10.1007/s13205-018-1202-6

37. Quadrana L, Colot V (2016) Plant transgenerational epigenetics. Annu Rev Genet 50:467-491. https://doi.org/10.1146/annurev-genet-120215-035254

38. Tellez-Plaza M, Tang WY, Shang Y, Umans JG, Francesconi KA, Goessler W et al (2014) Association of global DNA methylation and global DNA hydroxymethylation with metals and other exposures in human blood DNA samples. Environ Health Perspect 122(9):946-954. https://doi.org/10.1289/ehp.1306674

39. The Arabidopsis Information Resource (TAIR) (2021a) https://www.arabidopsis.org/servlets/TairObject? id=94303\&type=polyallele, on www.arabidopsis.org, Accessed 26 January 2021

40. The Arabidopsis Information Resource (TAIR) (2021b) https://www.arabidopsis.org/servlets/TairObject? id=500447108\&type=polyallele. on www.arabidopsis.org, Accessed 26 January 2021

41. Von Zglinicki T (2002) Oxidative stress shortens telomeres. Trends Biochem Sci 27(7):339-344. https://doi.org/10.1016/S0968-0004(02)02110-2

42. Wendte JM, Zhang Y, Ji L, Shi X, Hazarika RR, Shahryary Y et al (2019) Epimutations are associated with CHROMOMETHYLASE 3-induced de novo DNA methylation. Elife 8:e47891.

https://doi.org/10.7554/eLife.47891.001

43. Yang Y, Guo Y (2018) Elucidating the molecular mechanisms mediating plant salt-stress responses. New Phytol 217(2):523-539. https://doi.org/10.1111/nph.14920

44. Yao Y, Bilichak A, Golubov A, Kovalchuk I (2012) ddm1 plants are sensitive to methyl methanesulfonate and $\mathrm{NaCl}$ stresses anda re deficient in DNA repair. Plant Cell Rep 31(9):1549-1561.

https://doi.org/10.1007/s00299-012-1269-1

45. Yokoi S, Bressan RA, Hasegawa PM (2002) Salt stress tolerance of plants. JIRCAS Working Report 23(1):25-33

46. Zangi M, Najjar MBB, Golalipour M, Aghdasi M (2020) met1 DNA Methyltransferase controls TERT gene expression: a new insight to the role of telomerase in development. Cell Journal 22(1):71-74. https://doi.org/10.22074/cellj.2020.6290

47. Zhang H, Zhu JK (2011) RNA-directed DNA methylation. Curr Opin Plant Biol 14(2):142-147. https://doi.org/10.1016/j.pbi.2011.02.003

48. Zhong L, Xu YH, Wang JB (2009) DNA-methylation changes induced by salt stress in wheat Triticum aestivum. Afr J Biotechnol 8(22):6201-6207. https://doi.org/10.5897/AJB09.1058

49. Zhu JK (2000) Genetic analysis of plant salt tolerance using Arabidopsis. Plant Physiol 124(3):941-948. https://doi.org/10.1104/pp.124.3.941

\section{Figures}




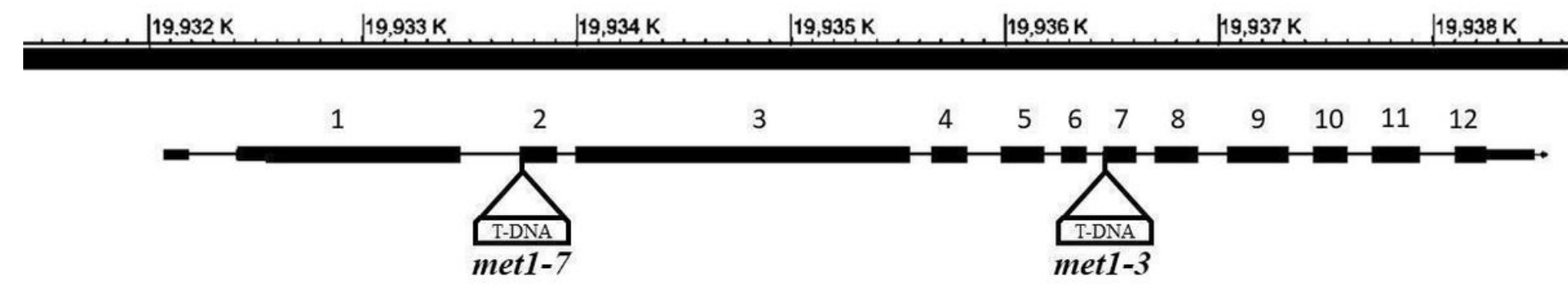

\section{Figure 1}

The locations of the T-DNA inserts in the met1-7 and met1-3 mutants (TAIR, 2021a and 2021b). 


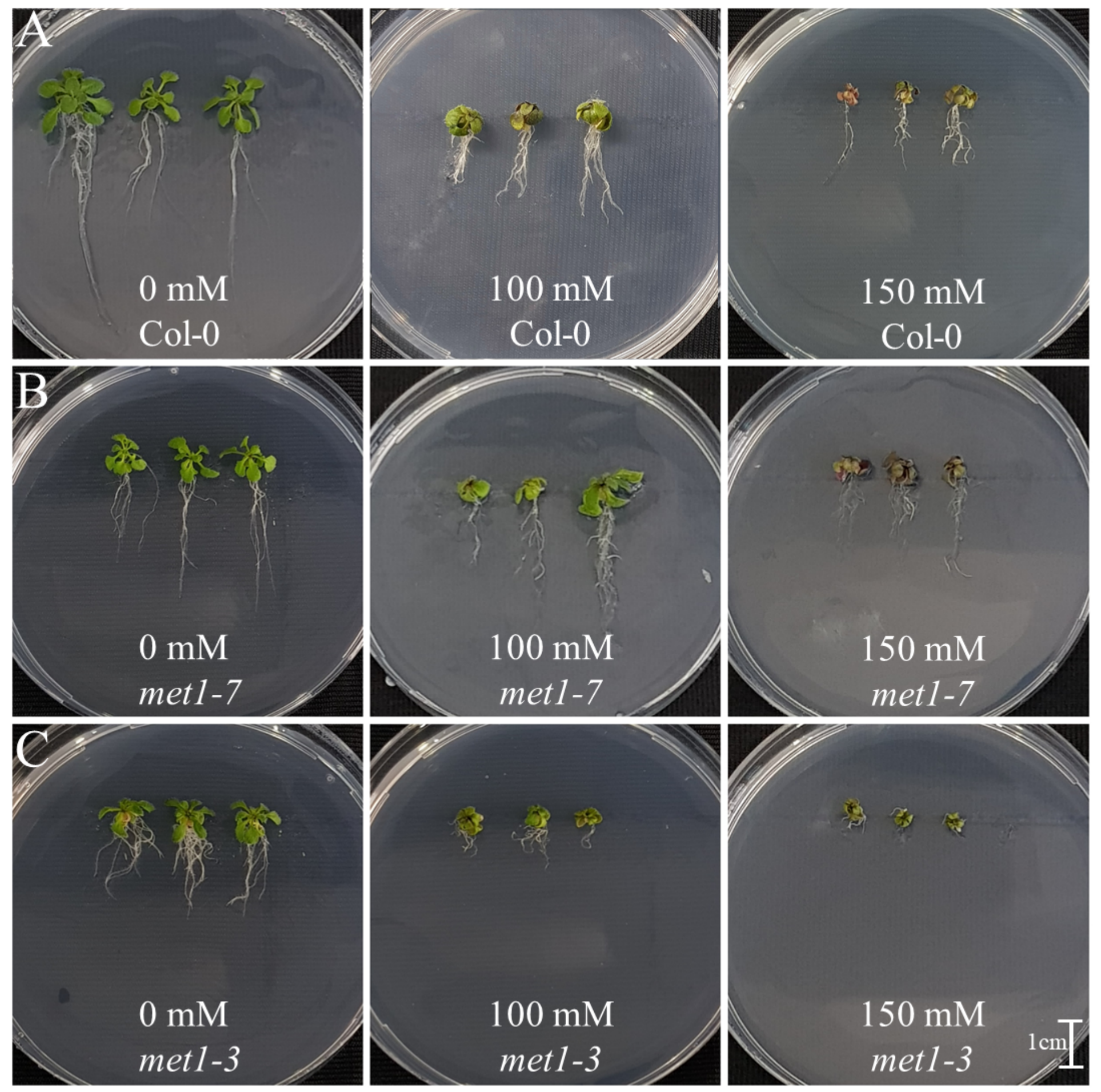

Figure 2

A. thaliana plants exposed to 0,100 and $150 \mathrm{mM} \mathrm{NaCl}$ during seven days. Row A belongs to Col-0 plants exposed to different concentrations of $\mathrm{NaCl}$. Row B belongs to met1-7plants exposed to different concentrations of $\mathrm{NaCl}$. Row $\mathbf{C}$ belongs to met1-3 plants exposed to different concentrations of $\mathrm{NaCl}$ 

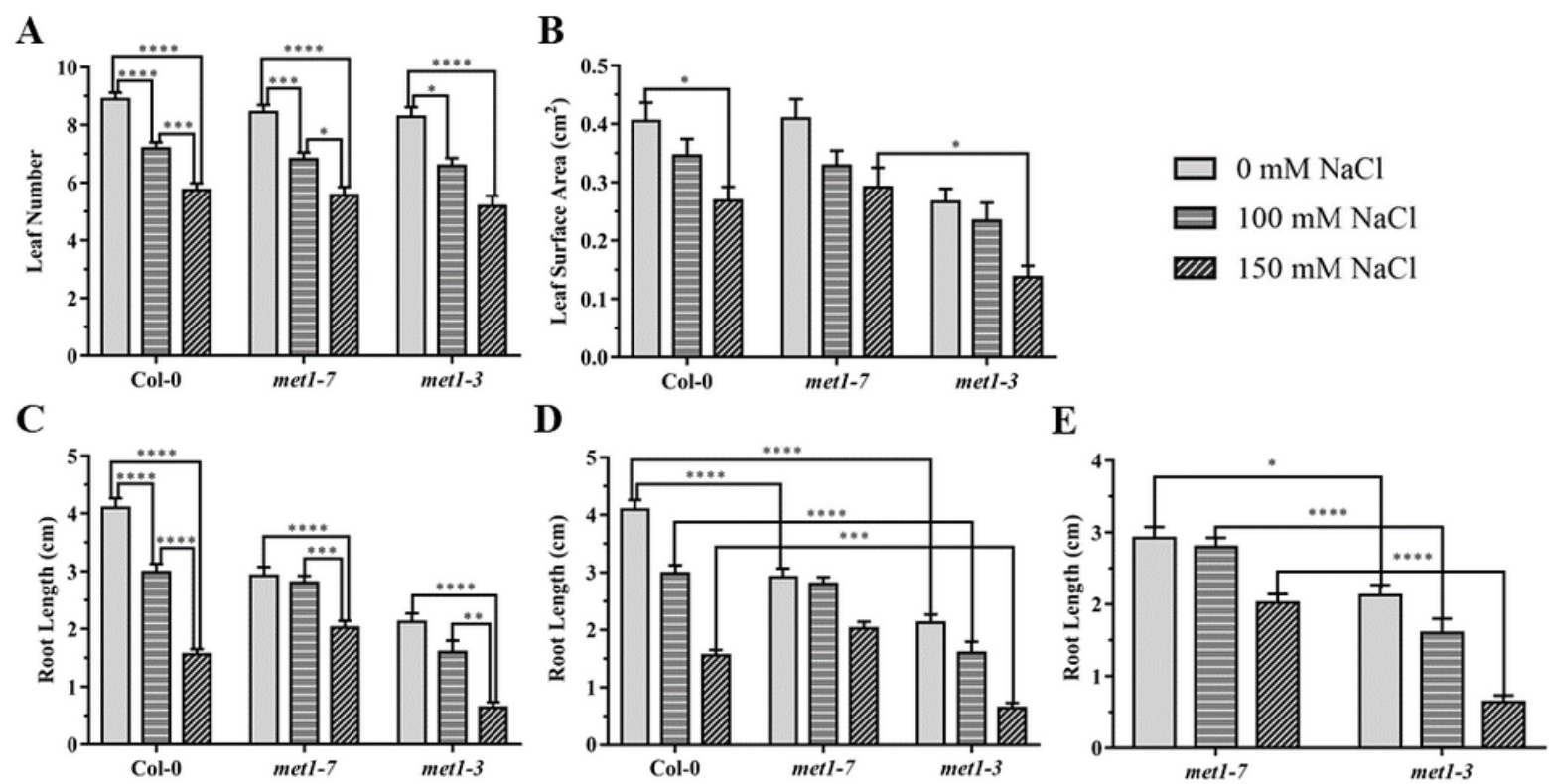

\section{Figure 3}

Morphological analysis of $A$. thaliana Col-0, met1-7 and met1-3 plants. A represents the differences between leaf numbers of plants exposed to 0,100 and $150 \mathrm{mM} \mathrm{NaCl}$. B represents the differences between leaf surface areas of plants exposed to 0,100 and $150 \mathrm{mM} \mathrm{NaCl}$ C represents the differences between root lengths of plants in each group individually exposed to 0,100 and $150 \mathrm{mM} \mathrm{NaCl} \mathbf{D}$ represents the differences in root lengths of plants exposed to 0, 100 and $150 \mathrm{mM} \mathrm{NaCl}$ between Col-0 and mutant groups E represents the differences in root lengths of plants exposed to 0,100 and $150 \mathrm{mM} \mathrm{NaCl}$ between met1-7 and met1-3 mutant groups 


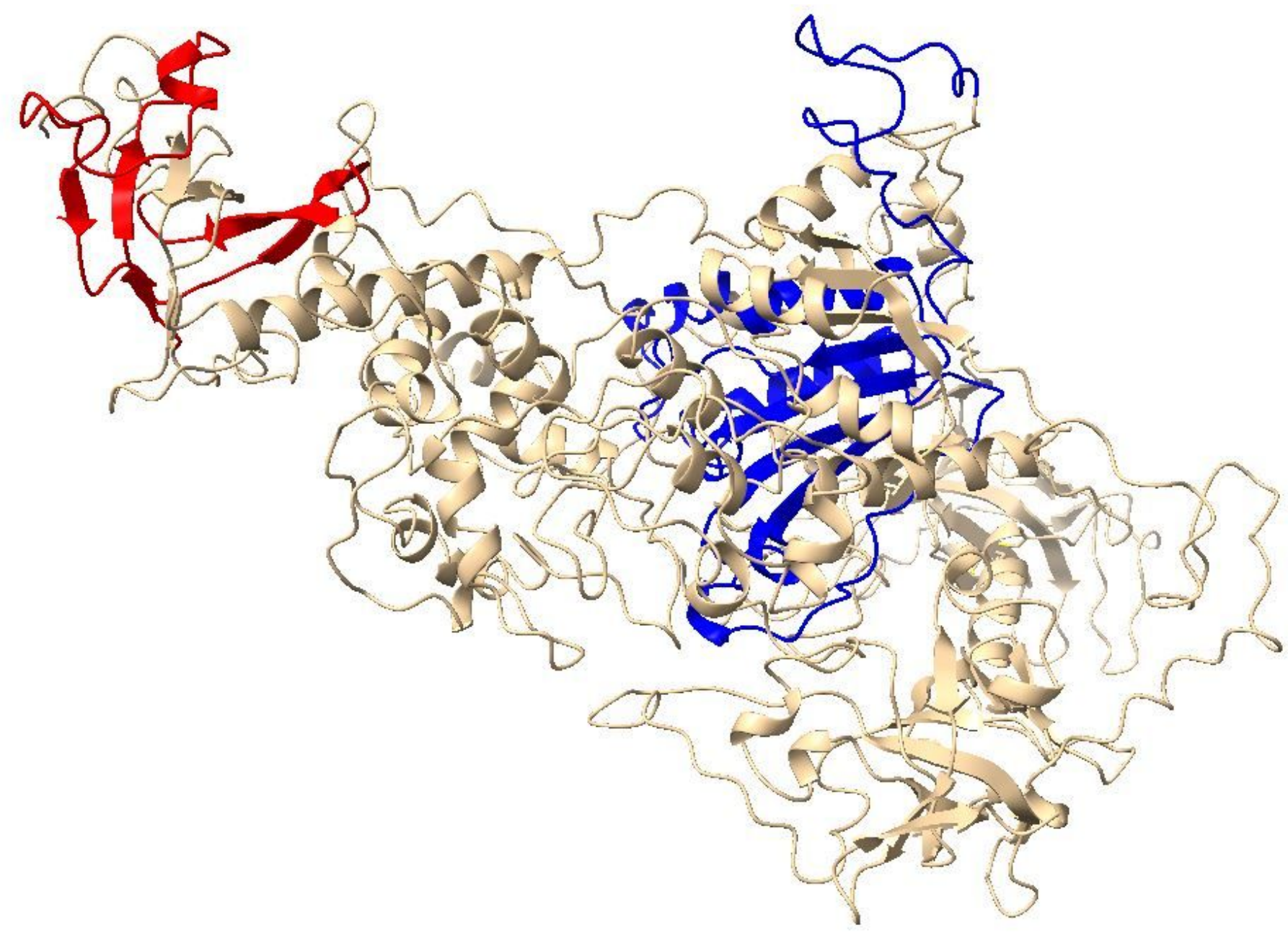

Figure 4

Representative image of the 3D structure of the methyltransferase 1 protein. The region shown in red in the image shows the location of the T-DNA insert entering the met7-7 mutant, and the region shown in blue shows the region where the T-DNA insert enters the met1-3 mutant and disrupts the protein structure 


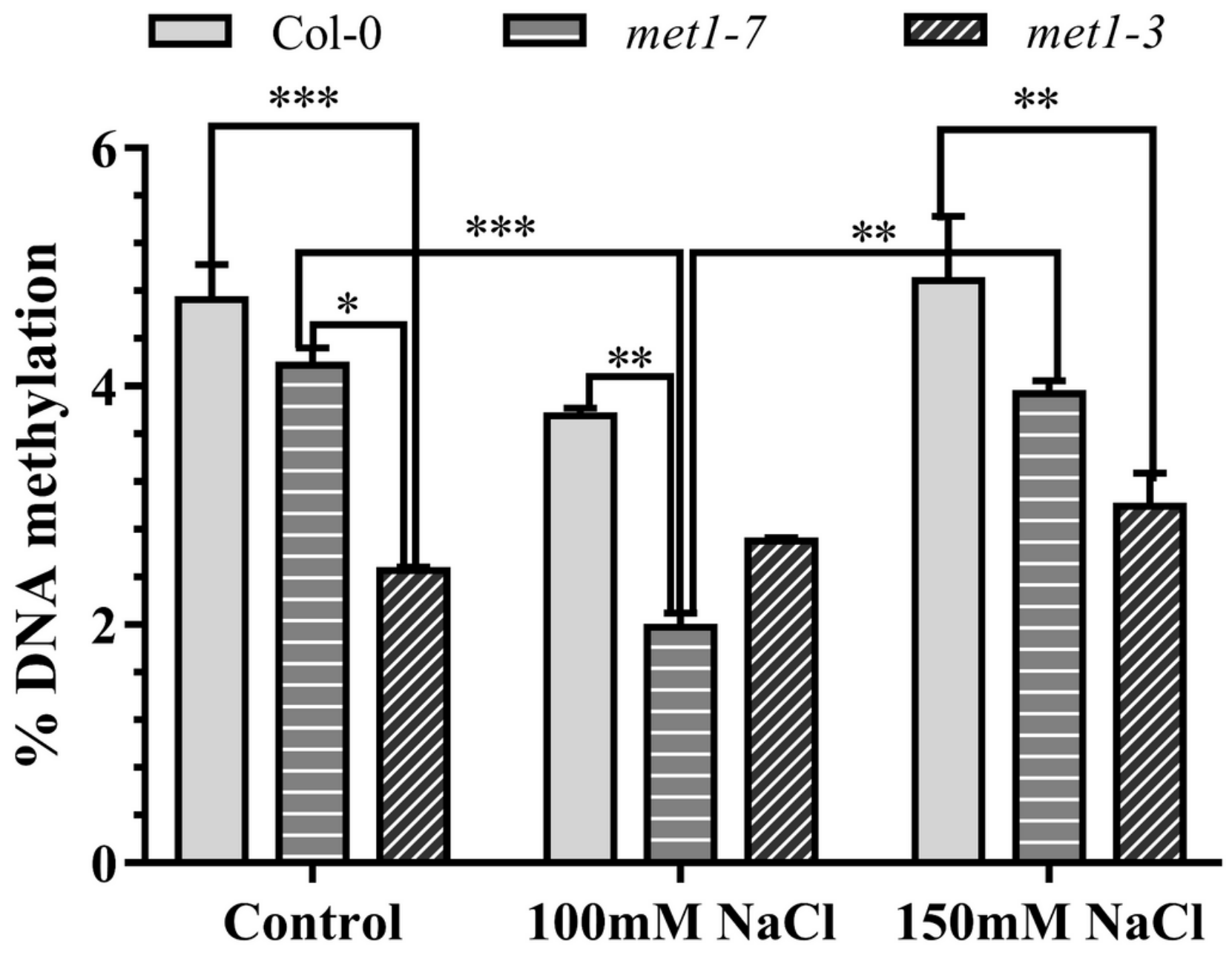

Figure 5

Graphical representation of the global DNA methylation change in percent (\%) of Col-0, met1-7 and met1-3 plants after different concentrations of $\mathrm{NaCl}$ treatment 


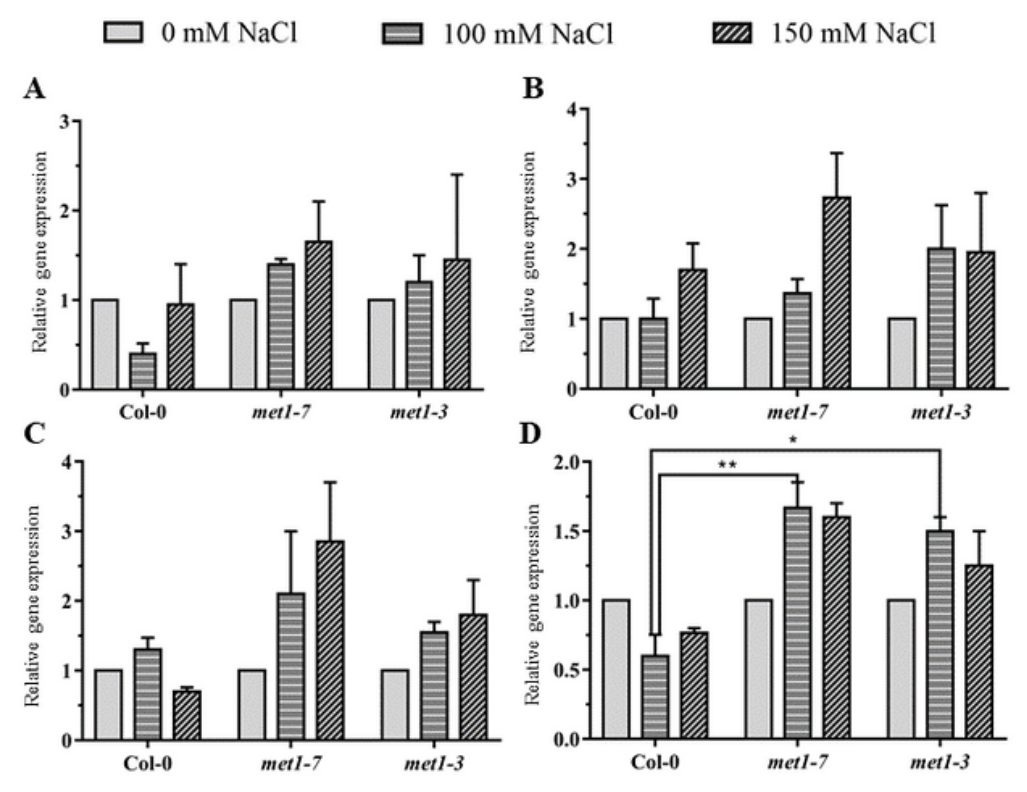

Figure 6

Relative gene expression analysis of Col-0, met7-7 and met7-3 plants. A: DRM2 gene, B: Pol IV gene, C: Pol V gene and $\mathbf{D}$ : TERT gene expression level 